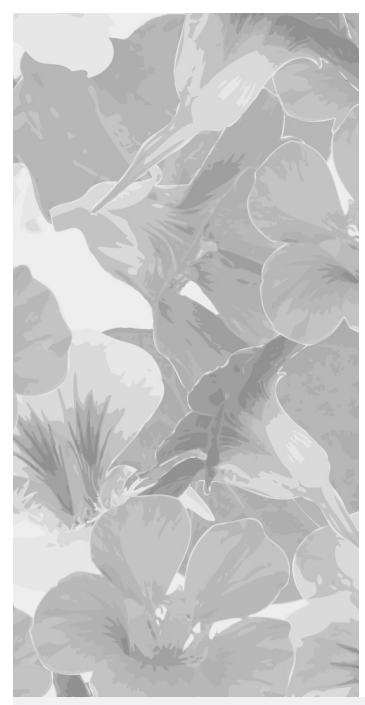

Food-provoked eczema: A hypothesis

on the possible role of systemic contact allergy to haptens present in both cosmetics and foods

\author{
Wyprysk prowokowany przez pokarmy: \\ Hipoteza na temat możliwej roli układowej alergii kontaktowej \\ na hapteny występujące w kosmetykach i pokarmach
}

Radosław Śpiewak

Institute of Dermatology, Krakow, Poland

Estetol Med Kosmetol 2011; 1(1): 35-40

DOI: http://dx.doi.org/10.14320/EMK.2011.006

\begin{abstract}
Patients with eczema frequently associate relapses of their disease with ingestion of particular foods, however, the actual causation by food allergens can be confirmed only in a minority of them. In the present paper, a hypothesis is proposed on the possible causal link between eczema and food in cases not explainable by type I allergy to "classical" food allergens like egg, milk or peanut protein. It is proposed that eczema in such cases may be due to delayed-type allergy to haptens present in food - either natural components, contaminants, or food additives. A wide range of haptens are used in the production of both food and cosmetics. It is proposed that initial sensitization of the skin to a hapten may follow external exposure (e.g. from skin care products), while relapses in the course of eczema may be due to subsequent oral exposures to the same hapten from food (systemic contact dermatitis). This hypothesis also offers an explanation for cases of photoaggravated eczema by indicating on food haptens with photosensitizing properties. The proposed hypothesis is unifying recent scientific discoveries and clinical observations in the attempt at explaining cases of food-provoked eczema that could not be explained by the present mainstream views on food allergy. Nevertheless, it requires thorough verification through dedicated research aimed specifically at testing the proposed causal relationship between food-provoked eczema and haptens occurring in both cosmetics and foods. If confirmed, appropriate diagnostic methods (e.g. patch test panels with food haptens or specially devised in vitro tests) should be introduced into routine diagnosis of eczema. Furthermore, results of such studies will provide scientific evidence for possible restrictions on the use of food additives identified as potent sensitizers within the legal scheme of consumer protection policy.
\end{abstract}

Key words: eczema, food allergy, food allergens, haptens, food additives, cosmetic ingredients

\title{
Streszczenie
}

Chorzy na wyprysk często wiążą nawroty swojej choroby ze spożyciem określonych pokarmów, jednak faktyczny związek z alergenami pokarmowymi udaje się potwierdzić zaledwie w mniejszości przypadków. Niniejszy artykut przedstawia hipotezę wyjaśniającą związek między wypryskiem a pokarmami w przypadkach, w których nie udaje się wykazać obecności alergii typu I na „klasyczne” alergeny pokarmowe, takie jak białka jaja, mleka, czy orzeszków ziemnych. Zgodnie z proponowaną hipotezą wyprysk w tych przypadkach może być wyrazem alergii opóźnionej na hapteny obecne w produktach spożywczych jako składniki naturalne, zanieczyszczenia lub dodatki spożywcze. Liczne hapteny są zarówno składnikami produktów spożywczych, jak i kosmetyków. W takich warunkach pierwotne uczulenie na hapten może następować na skutek kontaktu skórnego (np. produkty do pielęgnacji skóry), natomiast późniejsze nawroty wyprysku moga być prowokowane przez spożycie tych samych haptenów w pokarmie (układowy wyprysk kontaktowy). Niniejsza hipoteza może również wyjaśniać przypadki wyprysku nasilanego przez światło wskazując na występowanie w żywności haptenów o właściwościach fotouczulających. Przedstawiona hipoteza łączy nowe odkrycia naukowe i obserwacje kliniczne w celu wyjaśnienia przypadków wyprysku prowokowanego przez pokarmy, których nie da się wyjaśnić w oparciu o obecnie obowiązujące wyobrażenia na temat alergii pokarmowej. Dla potwierdzenia proponowanego związku przyczynowo-skutkowego między haptenami obecnymi w kosmetykach i pokarmach a wypryskiem prowokowanym przez pokarmy niezbędne są jednak dedykowane badania naukowe. Jeśli zostanie on potwierdzony, niezbędne stanie się wprowadzenie stosownych metod diagnostycznych (np. serii testów płatkowych z haptenami pokarmowymi lub dedykowanych testów laboratoryjnych) do rutynowej diagnostyki wyprysku. Wyniki takich badań dostarczą ponadto podstaw naukowych dla przyszłych regulacji prawnych chroniących konsumentów przed narażeniem na dodatki pokarmowe o silnym potencjale uczulającym.

Stowa kluczowe: wyprysk, alergia pokarmowa, alergeny pokarmowe, hapteny, dodatki pokarmowe, składniki kosmetyków

Copyright @ 2011 Radosław Śpiewak. All rights reserved.

Despite the fact that atopic eczema is associated by many patients with food allergy, experts have been aware for a long time that eczema lesions cannot be readily induced by provocation with food allergens [1]. Depending on the methodology, hypersensitivity to food allergens can be confirmed in $10 \%$ to $50 \%$ children with eczema [2-4]. In adolescents and adults, allergies to "classical" food allergens, such as hen's eggs and cow's milk are considerably less common and play a marginal role [3, 5]. Also, "elimination diets" aimed at curing eczema by excluding various "allergenic foods" remain ineffective in most cases, and the use of unjustified dietary regimens in infantile eczema has been criticized for more than five decades [6]. The simplistic approach "food allergy causes eczema" seems to be questioned in many ways, with recent evidence accumulating in favour 
of the opposite causal relationship, i.e. infantile eczema being the predisposing condition for a subsequent development of food allergy, rather than its consequence. Lack et al. [7] have demonstrated that the use of skin care products with peanut oil is a strong risk factor for the development of food allergy to peanuts later in life. In a mouse model, application of peanut extract or ovalbumin A on the abraded skin (thus made penetrable to proteins) both provokes inflammatory skin response with clinical appearance of delayed-type hypersensitivity (eczema) and induces production of IgE specific to these allergens [8]. Similar processes seem probable in humans with eczema - a disease inextricably linked with disruption of skin barrier. Putting the above information together, only in a fraction of eczema patients hypersensitivity to "classical" protein food allergens can be confirmed as the cause of their disease. As a matter of fact, food allergy may be secondary to eczema in many patients Allergies to food proteins do not seem to offer a plausible explanation for most of eczema patients, but many of them still insist that their skin problems are aggravated by ingestion of particular foods. In the present article, a hypothesis is proposed that links eczema provoked by food with food haptens, rather than "classical" protein food allergens.

\section{Haptens in food}

Haptens are small xenobiotic (exogenous) chemical molecules with molecular mass below 500 Dalton a size that allows them to penetrate through intact skin [9]. The possibility of hapten penetration through intestinal mucosa becomes obvious once one realizes that many oral drugs are also haptens [10]. There are numerous haptens in food, some of which are natural components (e.g. nickel, cobalt, vanillin) or contaminants (pesticides, animal drugs, industrial chemicals), while others are purposefully added during food processing (preservatives, emulsifiers, colorants, flavour enhancers, antioxidants). Haptens are not immunogenic, due to the fact that they are too small to be recognized by the immune system's antibodies or receptors. However, haptens can form immunogenic complexes with body's own proteins. Strong (mainly covalent) chemical bonds with haptens distort spatial conformation of endogenous proteins to such extent that these are no longer tolerated as body's own structures but instead induce immune reactions.

Haptens typically cause delayed type hypersensitivity, which means that symptoms may appear one or even several days after the ingestion. Under such circumstances, it is difficult for the patient or even doctor to trace down the causal link between flares of eczema and ingestion of a culprit hapten in food. Moreover, various foods may contain the same haptens, regardless their kind, brand name or taste. For example, balsam of Peru - a well- known skin sensitizer may be found in chewing gums, alcoholic drinks, salad dressings, filled chocolates, soft drinks, and a range of other flavoured products. As a result, certain haptens may accumulate from various, seemingly unrelated foods in a hardly traceable way. This might also lend a possible explanation for patients, who declare that they can tolerate small amounts of processed foods, but experience flares of eczema after indulging themselves with more.

\section{Breastfeeding and haptens}

In spite of extensive research, there is still no definitive proof for the effectiveness of breastfeeding in the prevention of food allergy and eczema [11]. Sometimes, flares of eczema in children fed exclusively on mother's milk are explained by an alleged passage of allergens into mother's milk from food that she ingests. It seems rather improbable, considering the fact that "classical" food allergens are proteins and as such undergo hydrolysis into amino acids in the maternal gastrointestinal (GI) tract. Nevertheless, some mothers still insist that they see a connection between their food intake and child's eczema flares. The present hypothesis offers an explanation for this, by indicating on the possibility of the child being sensitized to haptens in maternal milk. Drug distribution studies demonstrate that non-protein drugs may be actively or passively transferred from mother's GI tract to breast milk, which most probably is also true for other haptens [12, 13]. In contrast to "classical" allergenic proteins, haptens (occurring in cow milk naturally or as contaminants) would be also resistant to hydrolytic processes during production of hypoallergenic milk formulas. It seems, therefore, that infants may become exposed to food haptens regardless the way of their feeding.

\section{Photoaggravated eczema}

Most patients with eczema respond well to sunlight, and phototherapy is among relevant therapeutic options for this disease. In a subgroup of patients, however, sun exposure causes relapses or aggravations of eczema. On the ground of the present hypothesis, this might be explained by the presence of photosensitizing haptens in food. An example of such photohapten might be 2-phenylphenol, a fungicide with known photosensitizing properties that is used in the production of citrus fruits. Citrus fruits are frequently accused of causing skin problems, therefore the possibility of hypersensitivity to 2-phenylphenol or other pesticides seems worthwhile a dedicated study. The underlying processes would probably be analogous to drug-induced photoallergy or phototoxicity [14-17]. 


\section{The breach of tolerance to haptens}

Each day we are exposed to dozens of haptens, however, we remain tolerant of most (if not all) of them, indicating that the preferred response of the immune system is tolerance. Immune tolerance is an active process mediated by specialized subsets of antigen-specific lymphocytes [18]. The stimuli turning immune tolerance into hypersensitivity remain unclear, possible factors of importance with this respect include co-existence of irritation or inflammation ("danger signals"), co-exposures, previous exposures, UV-irradiation, site and the route of primary exposure [19-22]. Evidence accumulated from numerous animal and human studies (reviewed recently in [23]) demonstrates that primary oral exposure to haptens can prevent subsequent development of contact sensitization through the skin. However, the surface of human body is exposed to haptens already in utero, while oral exposure to highly processed (thus hapten-rich) foods occurs later in the course of life. This could facilitate the early development of hypersensitivity to haptens through the skin, rather than tolerance through oral exposure. With this regard, another hypothesis - proposed by McFadden and colleagues [24] that links oral exposure to haptens with food allergy deserves a mention. According to the authors, "artificially increased oral exposure to haptens compete with dietary proteins for the development of oral tolerance, predisposing to the acquisition of food protein allergy and representing one driver for the increasing prevalence of protein allergy and/or atopy". In another words, the authors suggest that oral exposure to food haptens would facilitate the development of allergy to "classical" protein food allergens, while the hypothesis outlined in the present article points on haptens themselves as the possible sensitizers in eczema. These hypotheses do not necessarily exclude one another, but rather seem to look at one complex phenomenon from different perspectives. Furthermore, McFadden et al. stated that "hapten exposure via other surfaces such as the skin and airways might also be important in promoting atopic disease". In the present hypothesis, the route of hapten exposure is regarded as a decisive factors, which is outlined in the following paragraphs.

\section{The possible role of cosmetics in food-related eczema}

The second part of this paper is aimed at explaining why would intestinal exposure to haptens result in eczema, i.e. inflammation localized in the skin. Data on the bioavailability of oral drugs [25] demonstrate that once absorbed from gastrointestinal (GI) tract into the blood, haptens may circulate to various organs of the body, where they can ultimately bind to autologous proteins and turn them into immunogens. This opens the question, why would haptens absorbed from food cause eczema and not any other organ's disease? The skin is one of the organs richest in immunocompetent cells, which makes it a good target for allergic reactions. However, the same is true for the gut or respiratory tract, yet flares of eczema are rarely accompanied by GI or respiratory symptoms. One possible explanation could be that some haptens are capable of forming complexes only with proteins present exclusively in the skin, e.g. keratins. This may be true in some cases, but seems rather insufficient as a general rule. Other, perhaps more convincing explanation might be the organ specificity of sensitization processes, rather than haptens themselves. The central element of acquired immune response are lymphocytes - cells capable of recognising specific hapten-protein complexes (HPC) that recruit and orchestrate inflammatory actions of other cells (e.g. macrophages, neutrophils, eosinophils, cytotoxic lymphocytes). There is evidence that naïve lymphocytes acquire organ specificity at their first encounter with HPC fitting to their receptors, presented to them by antigen presenting cells (APC) that migrate into local lymph nodes from the sites of haptens' entry. It appears that next to HPC, signals characteristic of the exposed organ are transmitted to naïve lymphocytes, which determines the organ-specificity of daughter effector and memory cells. These signals could be molecules carried on the surface of an APC, chemokines or other factors dissolved in the lymph draining particular organs. Thus in case of hapten-protein complex presented by an APC from the skin, in the milieu of a lymph node flooded with the lymph from the skin, the antigen specific naïve $\mathrm{T}$ cell will ultimately undergo clonal expansion into skin-homing effector and memory lymphocytes [26-30]. Some of the daughter lymphocytes will settle in the skin, while other will circulate in the blood ready for rapid migration into the skin in case of re-exposure to the hapten. While the induction of contact hypersensitivity seems to require the epidermal route, subsequent elicitations of the disease in already sensitized subjects may follow systemic exposure to the hapten, e.g. by oral route. Hapten absorbed from the GI tract will distribute not only into the skin, but obviously also to another organs of the body, however, the skin will be most affected by the inflammatory response due to predominance of skin-homing effector lymphocytes. As a matter of fact, cases of eczema provoked by oral or parenteral exposure to haptens are well-known to clinicians and are referred to as "hematogenous allergic contact dermatitis", "hematogenous contact eczema", "systemic contact dermatitis" or "systemic allergic contact dermatitis" (SACD) [31-35].

In summarising, the occurrence of the same haptens in cosmetics and food might offer an explanation for cases of eczema provoked by food that could not be explained by type I allergy to protein allergens. According to the 
present hypothesis, such patients may be sensitized to haptens - initially from cosmetics applied onto the skin (induction of hypersensitivity), with further relapses of eczema triggered by the same haptens absorbed from ingested food (elicitation of hematogenous eczema). As there are numerous haptens common to cosmetics and food products (table 1), these processes are very probable to occur in everyday life and deserve further studies. Repeated applications of cosmetics onto the skin seem a very effective way of inducing contact hypersensitivity to haptens, however, in small children the food might bypass the "cosmetic link", serving as a primary source of sensitizing haptens, as it is not unusual in children to have their food smeared over faces and hands during their meals.

\section{Future outlook}

The hypothesis presented in this paper requires thorough verification by the means of dedicated studies. One

Table 1. An overview of haptens that are both food additives and cosmetic ingredients (data extracted from [36])

\begin{tabular}{|c|c|c|}
\hline Hapten & Occurrence in cosmetic products & Occurrence in food \\
\hline 2,6-di-tert-butyl-4-cresol & Antioxidant in cosmetics & Antioxidant in foods (beverages, gum, ice cream, fruits, cereals) \\
\hline 2-phenylphenol & Preservative in cosmetics & Agricultural fungicide for citrus fruits \\
\hline 2-tert-butyl-4-methoxyphenol (BHA) & Antioxidant in cosmetics & Antioxidant in foods (beverages, gum, ice cream, fruits, cereals) \\
\hline Balsam Peru & Fixative and fragrance in perfumery & Flavour in tobacco, drinks, pastries, cakes, wines, liquors, spices, etc. \\
\hline Benzoic acid & Preservative in perfumes, cosmetics and dentifrices & Preservative in foods (fats, fruit juices, etc.) \\
\hline Benzyl alcohol & Enhancer and fixer in perfumery products & Food additive E1519. Natural occurrence in tea \\
\hline Benzyl benzoate & Fixative in fragrances & In artificial food flavours \\
\hline Benzyl cinnamate & Fixative in fragrances & Commonly used flavouring agent (sweet, floral, fruity) \\
\hline Bithionol & Deodorant, antibacterial agent in soaps, and other cosmetics & $\begin{array}{l}\text { Food additive, additive in animal feed and drinking water for farm } \\
\text { animals }\end{array}$ \\
\hline Butyl-4-hydroxybenzoate (Butylparaben) & Preservative in creams, lotions, ointments and other cosmetics & $\begin{array}{l}\text { Preservative in foods (salad dressings, mayonnaise, spiced sauces, } \\
\text { mustard, frozen dairy products, baked products) }\end{array}$ \\
\hline R-(L)-carvone & Toothpaste, perfumery & $\begin{array}{l}\text { Natural occurrence in lemon, orange, mandarin, grapefruit, clove oil, } \\
\text { eucalyptus, juniper berry, lavender, marjoram, ginger grass, Scotch } \\
\text { spearmint, garden mint, common spearmint }\end{array}$ \\
\hline Cinnamic alcohol & Perfumed cosmetic products and deodorants & Natural occurrence in cinnamon \\
\hline Cinnamic aldehyde & Deodorizers, toothpaste, detergents, soaps & $\begin{array}{l}\text { Natural occurrence in cinnamon. Flavour in sweets, ice cream, soft } \\
\text { drinks, chewing gums, cakes }\end{array}$ \\
\hline Coumarin & Perfumes, soaps & Natural occurrence in strawberries \\
\hline Captan & Preservative in soaps, shampoos, hair tonics & Preservative of fruits and other foods \\
\hline Dodecyl gallate & Antioxidant in cosmetic creams and emulsions & Antioxidant in margarine \\
\hline Ethyl-4-hydroxybenzoate (Ethylparaben) & Preservative in cosmetics & $\begin{array}{l}\text { Preservative in foods (salad dressings, mayonnaise, spiced sauces, } \\
\text { mustard, frozen dairy products, bakery products) }\end{array}$ \\
\hline Eugenol & Perfume & Chemical intermediate and contaminant in vanillin \\
\hline Farnesol & Perfume & Food flavour \\
\hline Isoeugenol & Perfume & Chemical intermediate and contaminant in vanillin, food flavour \\
\hline Juniper tar (Cade oil) & Perfume & Flavouring of meat and seafood (smoke note) \\
\hline Methyl-4-hydroxybenzoate (Methylparaben) & Preservative in cosmetics & $\begin{array}{l}\text { Preservative in salad dressings, mayonnaise, spiced sauces, mustard, } \\
\text { frozen dairy products, baked products }\end{array}$ \\
\hline Octyl gallate & Antioxidant in cosmetic products & Antioxidant in food products such as margarine and peanut butter \\
\hline Olive oil & In emollients, soaps, other cosmetics & Used as food (salads, sardines, etc.) \\
\hline Polyethyleneglycol (PEG 400) & Solvent and lubricant in cosmetics, detergents and soaps & Lubricant in food processing and packaging \\
\hline Propolis & Flavour in toothpaste, mouthwashes & Flavour in chewing gum \\
\hline Propyl gallate & Preservative and antioxidant in cosmetics & Food preservative and antioxidant (margarine, peanut butter, etc.) \\
\hline Propyl-4-hydroxybenzoate (Propylparaben) & Preservative in cosmetics & $\begin{array}{l}\text { Preservative in foods (salad dressings, mayonnaise, spiced sauces, } \\
\text { mustard, frozen dairy products, baked products), mould control in } \\
\text { sausage casings }\end{array}$ \\
\hline Propylene glycol & $\begin{array}{l}\text { Vehicle in cosmetic bases, present in cleansing creams, suntan lotions, } \\
\text { perfumes }\end{array}$ & Solvent for colours and flavours in food \\
\hline Sodium benzoate & Common preservative in cosmetic products & Preservative in food products (drinks, jams, jellies, pickles, syrups, etc.) \\
\hline Sorbic acid & Preservative in cosmetics & $\begin{array}{l}\text { Mould and yeast inhibitor and fungistatic agent for foods, especially } \\
\text { cheese }\end{array}$ \\
\hline Titanium oxide & $\begin{array}{l}\text { Mineral sunscreen agent, pigment and thickener in cosmetic and skin care } \\
\text { products, toothpaste }\end{array}$ & Food additive E171, white colouring agent in food \\
\hline Tocopherol (Vitamin E) & $\begin{array}{l}\text { Antioxidant in many cosmetics, often labeled as tocopherol acetate, } \\
\text { tocopheryl linoleate or tocopheryl nicotinate }\end{array}$ & $\begin{array}{l}\text { Natural occurrence in vegetable oils (soybean), nuts, seeds. Widely used } \\
\text { as an antioxidant in foods }\end{array}$ \\
\hline Trans-anethole & Perfume in soaps, dentifrices, etc. & Flavouring agent in foods \\
\hline Vanillin & Perfume & Flavouring agent in beverages, confectionery and other foods \\
\hline
\end{tabular}


such study should focus on the prevalence of contact hypersensitivity to food additives among patients with food-provoked eczema. Such patients should be tested with an array of haptens used as food additives or naturally occurring in foods. Cosmetic ingredients with recognised sensitizing potential that are also used as food additives (table 1) seem very promising candidates for such studies, however, other food-specific haptens either natural, contaminants or additives - should also be taken into consideration. After confirming the role of hypersensitivity to food haptens in food-provoked eczema, appropriate diagnostic methods (e.g. patch test panels with food haptens or specially devised in vitro tests) should be introduced into routine diagnosis of eczema patients. Furthermore, results of such studies will provide scientific evidence for possible restrictions on the use of food additives identified as potent sensitizers within the legal scheme of consumer protection policy.

\section{References}

1. Hanifin JM: Critical evaluation of food and mite allergy in the management of atopic dermatitis. J Dermatol 1997; 24(8): 495-503.

2. Barnetson RS, Rogers M: Childhood atopic eczema. BMJ 2002; 324(7350): 1376-9.

3. Werfel T, Ballmer-Weber B, Eigenmann PA, Niggemann B, Rance F, Turjanmaa K, Worm M: Eczematous reactions to food in atopic eczema: position paper of the EAACI and GA2LEN. Allergy 2007; 62(7): 723-8.

4. Devillers AC, de Waard van der Spek FB, Mulder PG, Oranje AP: Delayed- and immediate-type reactions in the atopy patch test with food allergens in young children with atopic dermatitis. Pediatr Allergy Immunol 2009; 20(1): 53-8.

5. Oranje AP, Bruynzeel DP, Stenveld HJ, Dieges PH: Immediate- and delayed-type contact hypersensitivity in children older than 5 years with atopic dermatitis: a pilot study comparing different tests. Pediatr Dermatol 1994; 11(3): 209-15.

6. Hill LW: The importance of contact eczema in children. Pediatrics 1959; 23(4): 797-801.

7. Lack G, Fox D, Northstone K, Golding J: Factors associated with the development of peanut allergy in childhood. N Engl J Med 2003; 348(11): 977-85.

8. Strid J, Hourihane J, Kimber I, Callard R, Strobel S: Disruption of the stratum corneum allows potent epicutaneous immunization with protein antigens resulting in a dominant systemic Th2 response. Eur J Immunol 2004; 34(8): 2100-9.

9. Bos JD, Meinardi MM: The 500 Dalton rule for the skin penetration of chemical compounds and drugs. Exp Dermatol 2000; 9(3): 165-9.

10. Cavani A, Ottaviani C, Nasorri F, Sebastiani S, Girolomoni G: Immunoregulation of hapten and drug induced immune reactions. Curr Opin Allergy Clin Immunol 2003; 3(4): 243-7.

11. Gahagan S: No reduction in risk in childhood asthma/ allergy symptoms found with longer breast-feeding. J Pediatr 2008; 152(3): 441-2.
12. Berlin CM Jr: Sensitivity of the young infant to drug exposure through human milk. Adv Drug Deliv Rev 2003; 55(5): 687-93.

13. Fleishaker JC: Models and methods for predicting drug transfer into human milk. Adv Drug Deliv Rev 2003; 55(5): 643-52.

14. Śpiewak R: Fotoalergie. Post Dermatol Alergol 2009; 26(5): 347-9.

15. Śpiewak R: Pathomechanisms of phototoxic dermatitis. In: Photoallergy and Photopatch Testing, ed. Śpiewak R. Institute of Dermatology, Krakow 2009: 20-2.

16. Śpiewak R: Pathomechanisms of photoallergic dermatitis. In: Photoallergy and Photopatch Testing, ed. Śpiewak R. Institute of Dermatology, Krakow 2009: 23-6.

17. Śpiewak R: Systemic photoallergy to terbinafine. Allergy 2010; 65(8): 1071-2.

18. Jonuleit H, Schmitt E, Kakirman H, Stassen M, Knop J, Enk AH: Infectious tolerance: human CD25(+) regulatory T cells convey suppressor activity to conventional CD4(+) T helper cells. J Exp Med 2002; 196(2): 255-60.

19. Draeger $\mathrm{H}, \mathrm{Wu} \mathrm{X}$, Roelofs-Haarhuis K, Gleichmann E: Nickel allergy versus nickel tolerance: can oral uptake of nickel protect from sensitization? J Environ Monit 2004; 6(12): $146 \mathrm{~N}-50 \mathrm{~N}$.

20. Novak N, Allam JP, Betten H, Haberstok J, Bieber T: The role of antigen presenting cells at distinct anatomic sites: they accelerate and they slow down allergies. Allergy 2004; 59(1): 5-14.

21. Parish IA, Waithman J, Davey GM, Belz GT, Mintern JD, Kurts C, Sutherland RM, Carbone FR, Heath WR: Tissue destruction caused by cytotoxic T lymphocytes induces deletional tolerance. Proc Natl Acad Sci USA 2009; 106(10): 3901-6.

22. Vocanson M, Hennino A, Rozieres A, Poyet G, Nicolas JF: Effector and regulatory mechanisms in allergic contact dermatitis. Allergy 2009; 64(12): 1699-714.

23. Śpiewak R: Immunotherapy of allergic contact dermatitis. Immunotherapy 2011; 3(8): 979-96.

24. McFadden JP, White JM, Basketter DA, Kimber I: Does hapten exposure predispose to atopic disease? The hapten-atopy hypothesis. Trends Immunol 2009; 30(2): $67-74$.

25. Oie S: Drug distribution and binding. J Clin Pharmacol 1986; 26(8): 583-6.

26. Akdis CA, Akdis M, Simon HU, Blaser K: Regulation of allergic inflammation by skin-homing $\mathrm{T}$ cells in allergic eczema. Int Arch Allergy Immunol 1999; 118(2-4): 140-4.

27. Novak N, Bieber T: The skin as a target for allergic diseases. Allergy 2000; 55(2): 103-7.

28. Moed H, Boorsma DM, Stoof TJ, von Blomberg BM, Bruynzeel DP, Scheper RJ, Gibbs S, Rustemeyer T: Nickel-responding $\mathrm{T}$ cells are CD4+ CLA+ CD45RO+ and express chemokine receptors CXCR3, CCR4 and CCR10. Br J Dermatol 2004; 151(1): 32-41.

29. Moed H, Boorsma DM, Tensen CP, Flier J, Jonker MJ, Stoof TJ, von Blomberg BM, Bruynzeel DP, Scheper RJ, Rustemeyer T, Gibbs S: Increased CCL27-CCR10 expression in allergic contact dermatitis: implications for local skin memory. J Pathol 2004; 204(1): 39-46.

30. Fuhlbrigge RC, Weishaupt C: Adhesion molecules in cutaneous immunity. Semin Immunopathol 2007; 29(1): 45-57. 
31. Veien NK: Systemically induced eczema in adults. Acta Derm Venereol Suppl (Stockh) 1989; 147: 1-58.

32. Fisher AA: . Systemic contact dermatitis caused by ingestion of certain foods in propylene glycol-sensitive patients. Am J Contact Dermat 1996; 7(4): 259.

33. Raison-Peyron N, Meynadier JM, Meynadier J: Sorbic acid: an unusual cause of systemic contact dermatitis in an infant. Contact Dermatitis 2000; 43(4): 247-8.

34. Erdmann SM, Werfel T: Hämatogene Kontaktekzeme durch Nahrungsmittel. Hautarzt 2006; 57(2): 116-20.

35. Nosbaum A, Ben Said B, Halpern SJ, Nicolas JF, Berard F: Systemic allergic contact dermatitis to black cumin essential oil expressing as generalized erythema multiforme. Eur J Dermatol 2011; 21(3): 447-8.

36. Chemotechnique Diagnostics AB: Hapten search.

URL: http: //www.chemotechnique.se (electronic document, accessed on 10 October 2011).

\section{Financing and conflict of interest}

The author has prepared this article entirely in his spare time and at his own expense, and declares no conflict of interest with regard to its content.

\section{Address for correspondence}

Prof. UJ Radoslaw Spiewak

Institute of Dermatology

ul. Lentza 6 M 17, 31-312 Krakow, Poland

email: spiewak.eu@gmail.com

Submitted: 13 September 2011

Accepted: 18 October 2011

Amended: 7 December 2011

Amended: 13 December 2011 